\title{
New insights into the organophosphate-induced intermediate syndrome
}

\author{
Raluca Ecaterina Haliga ${ }^{1}$, Bianca Codrina Morarasu², Manuela Ursaru³, Viorica Irimioaia ${ }^{4}$, and \\ Laurentiu Sorodoc ${ }^{1}$ \\ Department of Internal Medicine and Toxicology ${ }^{1}$, Department of Internal Medicine ${ }^{2}$, Department of Radiology and \\ Imaging, Department of Neurology , "Sf. Spiridon” Clinical Emergency Hospital, University of Medicine and \\ Pharmacy "Gr. T. Popa” Iasi, Romania
}

[Received in March 2018; Similarity Check in March 2018; Accepted in May 2018]

\begin{abstract}
Acute organophosphate (OP) poisoning can be deadlier than any other type of chemical poisoning. So far, only a few cases have been described that include extensive neurological complications. We present an outstanding case of severe oral OP poisoning with intermediate syndrome developed on the fourth day after hospital admission. The clinical picture involved weakness of the proximal upper and lower limb muscles and several muscles supplied by motor cranial nerves, but, what is peculiar, the distal upper and lower limb muscles were also affected (forearms, hands, legs, and feet). To our knowledge, this is a unique presentation, as lower limb muscle weakness was reported only in the context of delayed polyneuropathy. Another remarkable feature was the involvement of six of the twelve cranial nerves, which makes this case of intermediate syndrome the first with such a spread of muscle weakness and provides new insights into the polymorphic clinical manifestations of acute OP poisoning.
\end{abstract}

KEY WORDS: cholinesterase; lower limb muscle weakness; motor cranial nerves; myasthenia; poisoning

Since Clermont developed the first synthetic organic phosphorus anticholinesterase compound in 1854, more than 50,000 organophosphate substances (OPs) have been discovered. Acute OP poisoning is frequent in developing countries with easy access to anticholinesterase insecticides. The World Health Organization estimates that it causes more than 250,000 deaths every year (1). In Romania we deal with severe poisoning, prolonged hospitalisation and high cost for this category of patients. Of particular interest are the neurological complications that can occur. There are three phases of neurological manifestation: acute cholinergic crisis (ACC), intermediate syndrome (IMS), and organophosphate-induced delayed polyneuropathy (OPIDP), first reported by Wadia (2).

ACC develops in the first minutes to hours of OP poisoning. Due to the anticholinergic action, it affects muscarinic and nicotinic peripheral receptors and the central nervous system. The clinical picture is shaped by muscarinic and nicotinic symptoms (3). It involves the respiratory and cardiovascular system with rhinorrhoea, bronchospasm, bronchorrhoea, cough or severe respiratory distress, bradycardia and hypotension, gastrointestinal symptoms with nausea, vomiting, diarrhoea, and abdominal cramps, or neurological signs with fasciculation, muscle paralysis, dizziness, confusion, and seizures (4). These may be

Correspondence to: Bianca Codrina Morarasu, Department of Internal Medicine, "Sf. Spiridon" Clinical Emergency Hospital, 1 Independentei St., Iasi, Romania, E-mail: morarasu.bianca.codrina@gmail.com considered typical manifestations of ACC. More serious complications that can lead to death include coma and acute respiratory failure requiring mechanical intubation and ventilation (5).

OPIDP emerges within two to four weeks after exposure to OP insecticides and is characterised by lower limb muscle weakness, followed by progress toward upper limb muscles. After affecting the pyramidal tract, it leads to extrapyramidal symptoms characterised by spasticity or abnormal reflexes. Recovery can be complete in young patients, but neurological impairment may persist in certain cases (6).

IMS following acute OP poisoning is a complication with an incidence between $7.7 \%$ and $84 \%$ (7). This variability seems to be due to the great differences in defining IMS among studies. Generally, it appears two to four days after the cholinergic crisis in patients with severe and prolonged acetylcholinesterase (AChE) inhibition. The classic symptom defining IMS is weakness affecting the respiratory and limb girdle muscles, as well as muscles supplied by motor cranial nerves. (8) Uncommon presentations of IMS include extrapyramidal symptoms, bilateral vocal cord paralysis, or even all the three neurological phases in the same patient (9-10). All of these seem to reflect a pathophysiological dysfunction of the neuromuscular junction due to the accumulation of acetylcholine in the synaptic cleft. Other mechanisms include muscle necrosis, oxidative stress-related myopathy, 
or persistent AChE inhibition (7). However, the pathophysiology underlying IMS is still not clear.

Here we present a case of severe IMS with weakness involving proximal and distal limb muscles and several muscles supplied by motor cranial nerves following acute ingestion of diazinon in a suicidal attempt of a 49-year-old woman. To our knowledge, this is the first report of IMS with such particular clinical presentation.

\section{CASE REPORT}

A 49-year-old woman ingested about $200 \mathrm{~mL}$ of diazinon in a suicide attempt. She had no prior medical history of suicidal thoughts or attempts. After approximately one hour from the ingestion, her family found her unconscious on the farm field. She had pulse but was unresponsive and sweating profusely, so the family took her to the local hospital. About one hour later, she received gastric lavage and activated charcoal and was then referred to our emergency department where she arrived two hours later with drowsiness, temporal and spatial disorientation, slur, generalised tremor, diaphoresis, cough, epigastric pain, nausea, and vomiting of white foam. Physical examination revealed hypotension (blood pressure 85/60 $\mathrm{mmHg}$ ), bradycardia (heart rate 60-64 bpm), hypoxia (oxygen saturation was $88-90 \%$ even on oxygen therapy delivering $\mathrm{O}_{2}$ at $4 \mathrm{~L} \mathrm{~min}^{-1}$ ), midsized pupils, diaphoresis, hypersalivation, rhonchi in the inferior lung fields, and epigastric tenderness. The baseline measurement of serum butyrylcholinesterase (BuChE) was $281 \mathrm{U} \mathrm{L}^{-1}$ (normal values 4260-11250 $\mathrm{U} \mathrm{L}^{-1}$ ). The chest X-ray (Figure 1) revealed a consolidation occupying the right inferior lung parenchyma.

Antidote treatment was started while the patient was in the emergency department, with two vials of $250 \mathrm{mg}$ obidoxime and nine vials of $1 \mathrm{mg}$ atropine with titration, both given intravenously (IV).

About two hours later, the patient was admitted to our toxicology department. On arrival, her blood pressure was $110 / 70 \mathrm{mmHg}$ and heart rate $114 \mathrm{bpm}$. She presented with dry skin, midsize pupils, persistent epigastric pain, nausea, and insecticide breath. Electrocardiogram (ECG) showed sinus tachycardia, and the full laboratory profile revealed leukocytosis, neutrophilia, increased C-reactive protein (CRP), fibrinogen, and abnormal urine findings due to the urinary tract infection with $E$. coli.

We continued antidote treatment with atropine and adjusted the doses to the signs of atropinisation; we started with one vial every $2 \mathrm{~h}$ for one day, then changed to every $4 \mathrm{~h}$ for the next three days, and finally to every $6 \mathrm{~h}$ for the next five days, after which atropine treatment was stopped. IV obidoxime was also continued for $72 \mathrm{~h}$ from admission to the toxicology department, and two units of fresh frozen plasma (FFP) were administered in the first two days. Serum BuChE was monitored regularly (Figure 2). The patient's general status improved with antidote treatment. Her haemodynamics was stable, oxygen saturation normal (no artificial ventilation was needed), pupils midsize, skin dry, and she was conscious and oriented. The cholinergic and digestive symptoms gradually receded and only a mild cough persisted. In spite of the atropine treatment, however, on the fourth day of admission to our toxicology department, the patient developed myoclonic twitches of the jaw and tremor of the head and arms. She complained of a generalised weakness and difficulty moving the limbs, standing, staying seated, and breathing due to respiratory muscle weakness. Neurological examination revealed myasthenia gravis due to OP poisoning. Her sensation was unaltered but with diminished tendon reflexes. Head computed tomography with contrast showed diffuse cerebral oedema (Figure 3). Lumbar puncture was normal. The treatment of the cerebral oedema started with a loop diuretic, but the patient's neurological status continued to decline. The next day she had the Glasgow Coma Score of 11, bilateral ptosis, and difficulty opening and closing her mouth. She could not chew, raise eyebrows, or smile. Clinical signs and symptoms of bulbar palsy were also present, along with dysphagia, hoarse voice, and inability to shrug or turn the head. Secretions from the respiratory tract were removed with bronchial endoscopy. Arterial blood gases were within the normal range. Electromyography was not performed. All these clinical, neurological, and radiological findings pointed to the diagnosis of an atypical
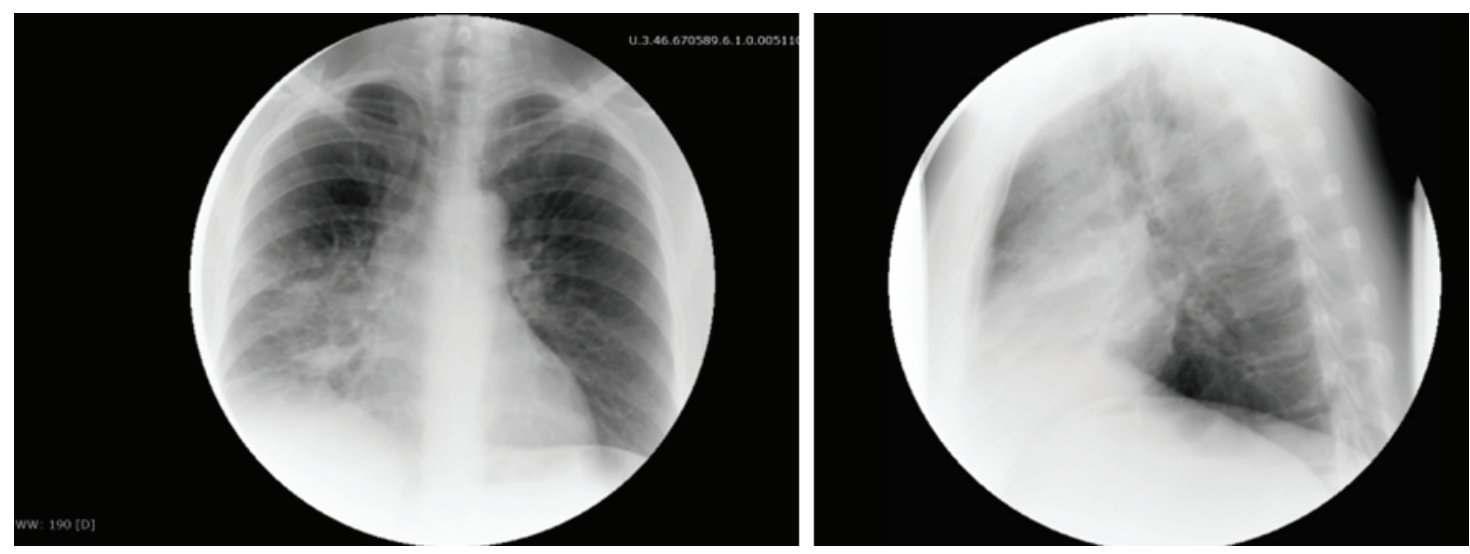

Figure $1 X$-ray of the patient poisoned with diazinon on admission 


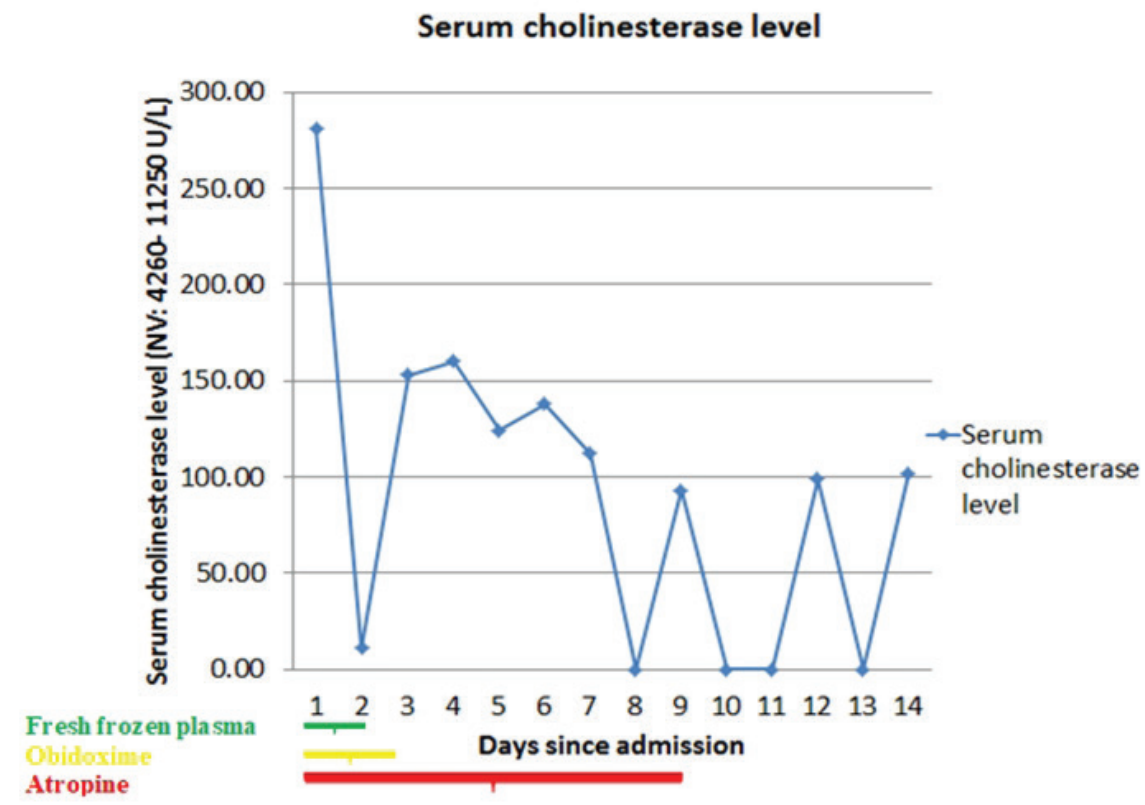

Figure 2 Serum cholinesterase levels in the patient poisoned with diazinon over the 14 days of hospitalisation

IMS due to severe OP poisoning. We introduced treatment with mannitol, group B vitamins, and haemoglobin glutamer (Actovegin) and kept the patient under close observation. To address respiratory and urinary tract infection we also introduced antibiotic treatment according to her antibiogram.

The patient's neurological status improved in the days that followed. She fully recovered from muscle weakness, but the signs of facial nerve palsy remained. She was discharged after 14 days in hospital and had been followed up periodically for the next year.

\section{DISCUSSION}

The clinical features and prognosis in OP poisoning depend on the type of pesticide, dose, route of administration, and the moment when treatment is initiated. With our patient, the culprit pesticide was a diethyl compound diazinon, the most common category of pesticide nowadays (11). A recent study by Peter et al. (12) showed that the diethyl group was associated with later onset and less severe symptoms than the dimethyl group of OPs. Also, the incidence of the IMS and the need for tracheostomy or intubation were significantly lower with the diethyl compounds. The diethyl group contains fat-soluble organophosphates that remain in the circulation in low levels and may persist for a longer period of time.

After ingestion, diazinon causes a rise in acetylcholine concentration with subsequent stimulation of the muscarinic and nicotinic receptors shaping the acute cholinergic syndrome (11). On admission, our patient had the classic hallmarks of this syndrome with hypotension, bradycardia, cough, nausea, vomiting, and abdominal pain due to muscarinic effects, accompanied by nicotinic manifestations.
Further confirmation of the diagnosis came with low serum $\mathrm{BuChE}$, which is a common finding among patients poisoned with OPs (13). Several studies found that the severity of poisoning and the need for intubation rose with lower plasma or serum levels (14-15). However, whether the level of serum cholinesterase correlates with the severity of poisoning is still a matter of debate.

In our case, serum BuChE was severely depressed, with only slight fluctuations throughout hospitalisation, despite optimal atropine and oxime therapy and the administration of two units of FFP over the first two days of admission to our toxicology department. This finding is consistent with the report by Pazooki et al. (16). In contrast, a prospective study (17) with 33 cases of OP poisoning, reported that nine patients treated only with atropine + pralidoxime developed IMS, while no IMS was observed in those who received atropine + pralidoxime + FFP. BuChE plasma levels were similar between the two groups on admission to the hospital, but in the FFP-treated group they increased by $461 \mathrm{U} \mathrm{L}^{-1}$ with every two bags of plasma given.

$\mathrm{BuChE}$ provided with plasma might play a role in sequestrating OPs in the circulation and stop further $\mathrm{AChE}$ inhibition. This may become extremely important when AChE activity is extremely low. In addition, FFP provides other important molecules, such as esterases and proteases, which may counteract the OP effects. How successfully will depend on the type of OP pesticides (18). Further research is therefore needed to better understand the effects of $\mathrm{BuChE}$ on the central nervous system (17).

IMS appears within the first 24 to $96 \mathrm{~h}$ of OP ingestion and can last up to six days. Recent studies, however, have shown that IMS may also occur outside this time frame, even after acute cholinergic crisis seems to have been resolved. Our patient's symptoms are the case in point: they 

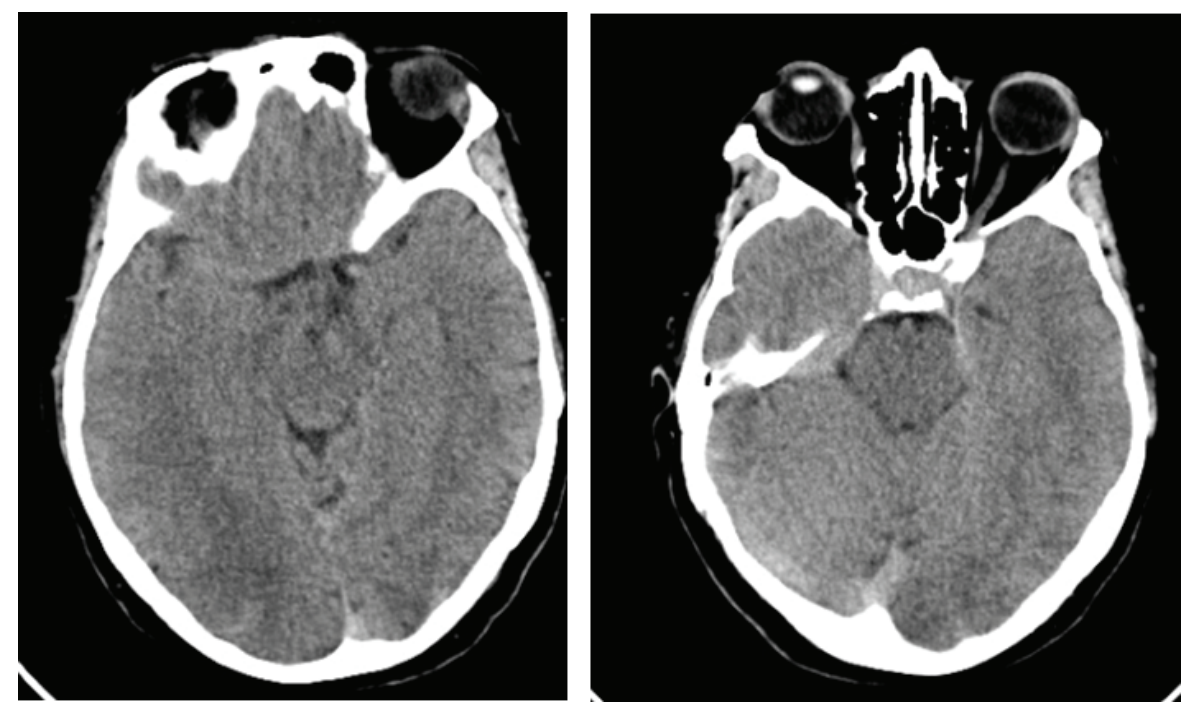

Figure 3 CT scan shows a discrete supra-tentorial loss of grey-white matter differentiation, with the effacement of the cerebral sulci and obliteration of supraselar and ambiens cisterns. There are no signs of uncal herniation

seemed to have improved, but $72 \mathrm{~h}$ after admission, she developed a weakness in several muscle groups. Our findings correspond to the clinical features of IMS first described in 1987 (19) as weakness of the neck flexors, respiratory, proximal limb muscles, and certain muscles supplied by motor cranial nerves.

One of the most important complications, however, is the respiratory failure requiring intubation and mechanical ventilation (20). It can appear in $24-66 \%$ of patients and directly correlates with the severity of poisoning. Other risk factors for intubation/ventilation include pneumonia, acute pulmonary oedema, or cardiovascular collapse (21). Our patient remained stable (under constant monitoring), even though she was severely poisoned and developed pneumonia.

To the best of our knowledge, this is the first case reporting a distal limb muscle weakness. Our patient was unable to extend, flex or lift up her forearms, hands, legs, and feet. She was incapable to stand, sit, or walk. Her tendon reflexes were slower but the sensation was preserved. The weakness of the distal limbs was reported earlier only in the context of OPIDP, which develops two to three weeks after OPs poisoning. The clinical picture of OPIDP includes weakness and numbness in the lower limbs, followed by progression toward the upper limbs (6). Symptoms may last for up to two years, but recovery can be complete, especially in young patients. In our case, the symptoms regressed to full resolution until discharge from the hospital.

Weakness in the muscle groups supplied by the $3^{\text {rd }}$ (bilateral ptosis), $5^{\text {th }}$ (inability to close the mouth or to chew), and $7^{\text {th }}$ (inability to smile and raise eyebrows) motor cranial nerve as well as the bulbar syndrome in our patient clearly point to multiple cranial nerve involvement. Literature does report that IMS may affect motor cranial nerves but not to such an extent $(19,22)$. In a study which evaluated IMS in 21 patients (23), 17 had weakness in the muscles supplied by motor cranial nerves and three had atypical manifestations with a relapse of acute cholinergic symptoms at the beginning of IMS. In our case, we noticed concomitant development of fasciculation in the jaw muscles and symptoms of IMS. This situation has already been reported in literature; De Bleecker et al. (14) observed that out of eight patients with IMS, six developed cholinergic symptoms, such as fasciculation, bradycardia, diarrhoea, sweating, lacrimation, and increased salivary and bronchial secretion.

\section{CONCLUSION}

Early recognition of muscle weakness before major complications appear can save lives. Our case stands out with an atypical IMS.

First, it is quite uncommon (although not unheard of) that acute cholinergic symptoms such as muscle fasciculation should appear at this stage.

Second, muscle weakness spread to the distal limbs, which has only been encountered in delayed polyneuropathy, bearing the risk of becoming a chronic condition. Fortunately, this symptom regressed within several days with the accompanying clinical manifestations.

Third, six of the twelve cranial nerves were involved, which makes this case of IMS the first with such an large extent of muscle weakness.

All these new findings in our case witness to the complex clinical picture of IMS that needs further research.

\section{Conflicts of interest}

None to declare.

\section{Acknowledgements}

We would like to thank our patient for consenting to the publication of this case report. 


\section{REFERENCES}

1. World Health Organization. The Impact of Pesticides on Health: Preventing Intentional and Unintentional Deaths from Pesticide Poisoning, 2004 [displayed 7 May 2018]. Available at http://www.who.int/mental_health/prevention/suicide/en/ PesticidesHealth2.pdf

2. Wadia RS, Chitra S, Armin RB, Kiwallkar RS, Sardesai HV Electrophysiological studies in acute organophosphate poisoning. J Neurol Neurosurg Psychiatry 1987;50:1441-8. PMCID: PMC1032555

3. Singh G, Khurana D. Neurology of acute organophosphate poisoning. Neurol India 2009;57:119-25. doi: 10.4103/00283886.51277

4. Peter JV, Cherian AM. Organic insecticides. Anaesth Intensive Care 2000;28:11-21. PMID: 10701030

5. Namba T. Cholinesterase inhibition by organophosphorus compounds and its clinical effects. B World Health Organ 1971;44:289-307. PMCID: PMC2428032

6. Lotti M, Moretto A. Organophosphate-induced delayed polyneuropathy. Toxicol Rev 2005;24:37-49. PMID 160425036.

7. Yang CC, Deng JF. Intermediate syndrome following organophosphate insecticide poisoning. J Chin Med Assoc 2007;70:467-72. doi: 10.1016/S1726-4901(08)70043-1

8. Karalliedde L, Baker D, Marrs TC. Organophosphateinduced intermediate syndrome: aetiology and relationships with myopathy. Toxicol Rev 2006;25:1-14. PMID: 16856766

9. Sarkar S, Nandi M, Mondal R, Mandal SK. Organophosphorusinduced extrapyramidal intermediate syndrome in an adolescent suicide attempt survivor. J Neurosci Rural Pract 2014:5:276-78. doi: 10.4103/0976-3147.133596

10. Azazh A. Severe organophosphate poisoning with delayed cholinergic crisis, intermediate syndrome and organophosphate induced delayed polyneuropathy on succession. Ethiop J Health Sci 2011;21:203-8. PMCID: PMC3275864

11. Gallo MA, Lawryk NJ. Organic phosphorus pesticides. In: Hayes WJ, Laws ER, editors. Handbook of Pesticide Toxicology. San Diego (CA): Academic Press; 1991. p. 917 1123.

12. Peter JV, Jerobin J, Nair A, Bennett A, Samuel P, Chrispal A, Abraham OC, Mathews KP, Fleming JJ, Oommen A. Clinical profile and outcome of patients hospitalized with dimethyl and diethyl organophosphate poisoning. Clin Toxicol 2010;48:916-23. doi: 10.3109/15563650.2010.528425
13. Chaudhary SC, Singh K, Sawlani KK, Jain N, Vaish AK, Atam V, Lal Patel M, Agarwal A. Prognostic significance of estimation of pseudocholinesterase activity and role of pralidoxime therapy in organophosphorous poisoning. Toxicol Int 2013;20:214-7. doi: 10.4103/0971-6580.121669

14. De Bleecker J, Van den Neucker K, Colardyn F. Intermediate syndrome in organophosphorus poisoning: a prospective study. Crit Care Med 1993;21:1706-11. PMID: 8222687

15. Areekul S, Srichairat S, Kirdudom P. Serum and red cell cholinesterase activity in people exposed to organophosphate insecticides. Southeast Asian J Trop Med Public Health 1981;12:94-8. PMID: 7256362

16. Pazooki S, Solhi H, Vishteh HR, Shadnia S, Beigi MJ. Effectiveness of fresh frozen plasma as supplementary treatment in organophosphate poisoning. Med J Malaysia 2011;66:342-5. PMID: 22299554

17. Güven M, Sungur M, Eser B, Sari I, Altuntaş F. The Effects of fresh frozen plasma on cholinesterase levels and outcomes in patients with organophosphate poisoning. J Toxicol Clin Toxicol 2004;42:617-23. doi: 10.1081/CLT-200026967

18. von der Wellen J, Bierwisch A, Worek F, Thiermann H, Wille T. Kinetics of pesticide degradation by human fresh frozen plasma (FFP) in vitro. Toxicol Lett 2016;244:124-8. doi: 10.1016/j.toxlet.2015.07.014.

19. Senanayake N, Karalliedde L. Neurotoxic effects of organophosphorus insecticides. An intermediate syndrome. N Engl J Med 1987;316:761-3. doi: 10.1056/ NEJM198703263161301

20. Eddleston M, Mohamed F, Davies JO, Eyer P, Worek F, Sheriff MH, Buckley NA. Respiratory failure in acute organophosphorus pesticide self-poisoning. QJM 2006;99:513-22. doi: 10.1093/qjmed/hc1065

21. Peter JV, Sudarsan TI, Moran JL. Clinical features of organophosphate poisoning: A review of different classification systems and approaches. Indian J Crit Care Med 2014;18:735-45. doi: 10.4103/0972-5229.144017

22. De Bleecker J, Vogelaers D, Ceuterick C, Van Den Neucker $\mathrm{K}$, Willems J, De Reuck J. Intermediate syndrome due to prolonged parathion poisoning. Acta Neurol Scand 1992;86:421-4. doi: 10.1111/j.1600-0404.1992.tb05110.x

23. He F, Xu H, Qin F, Xu L, Huang J, He X. Intermediate myasthenia syndrome following acute organophosphates poisoning - an analysis of 21 cases. Hum Exp Toxicol 1998;17:40-45. doi: 10.1177/096032719801700107

\section{Novi uvidi u intermedijarni sindrom uzrokovan trovanjem organofosfatnim pesticidom}

Akutno trovanje organofosfatima (OP) može biti smrtonosnije od bilo koje druge vrste trovanja kemikalijama. Dosada je opisano tek nekoliko slučajeva s neurološkim komplikacijama širokih razmjera. Ovdje donosimo prikaz jednog iznimnno teškog slučaja trovanja pacijentice diazinonom, u koje se intermedijarni sindrom javio četvrtoga dana hospitalizacije. Njezina klinička slika obuhvaćala je slabost u pojedinim mišićima proksimalnih dijelova gornjih udova povezanih $\mathrm{s}$ motornim kranijalnim živcima, ali ono što je neobično bila je slabost mišića u distalnim dijelovima donjih udova. Koliko znamo, to je jedinstven takav slučaj, s obzirom na to da je slabost u mišićima donjih udova opisana samo u kontekstu kasne polineuropatije. Uz to, ovaj se slučaj intermedijarnog sindroma ističe i dosad nezabilježenom zahvaćenošću šest od dvanaest kranijalnih živaca. Time je dobiven novi uvid u polimorfnu narav kliničkih manifestacija akutnog trovanja organofosfatima. 